\title{
Effect of Welsh onion (Allium fistulosum L.) green leaf extract on immune response in healthy subjects: a randomized, double- blind, placebo-controlled study
}

\author{
Yosuke Hirayama $^{1 *}$, Jun Takanari ${ }^{1}$, Kazunori Goto ${ }^{1}$, Hiroshi Ueda ${ }^{2}$, Aiko Tanaka ${ }^{3}$ \\ and Jun Nishihira ${ }^{3}$
}

\begin{abstract}
${ }^{1}$ Amino Up Co., Ltd., 363-32 Shin-ei, Kiyota, Sapporo, Hokkaido, 004-0839 Japan; ${ }^{2}$ Division of Vegetable Pest Management and Functional Analysis, Institute of Vegetable and Floriculture Science, National Agriculture and Food Research Organization, Tsu, Mie, 5142392, Japan; ${ }^{3}$ Department of Medical Management and Informatics, Hokkaido Information University, 59-2 Nishinopporo, Ebetsu, Hokkaido, 069-8585 Japan.
\end{abstract}

Corresponding author: Yosuke Hirayama, Amino Up Co., Ltd., 363-32 Shin-ei, Kiyota, Sapporo, Hokkaido, 004-0839 Japan

Submission Date: October $18^{\text {th }}, 2018$, Acceptance Date: February $25^{\text {th }}, 2019$, Publication Date: February $28^{\text {th }}, 2019$

Citation: Hirayam Y., Takanari J., Goto K., Ueda H., Tanaka A, Nishihira J. Effect of Welsh onion (Allium fistulosum L.) green leaf extract on immune response in healthy subjects: a randomized, double-blind, placebo-controlled study. Functional Foods in Health and Disease 2019; 9(2): 123-133. DOI: https://doi.org/10.31989/ffhd.v9i2.569

\begin{abstract}
Background: Welsh onion belongs to genus Allium. Although its medicinal benefits, such as cold prevention, are well known by tradition, the underlying mechanism and active components have never been elucidated. The recent study revealed that Welsh onion mucus enhances tumor necrosis factor- $\alpha$ and monocyte chemotactic protein-1 production from RAW 264 cells and natural killer (NK) cell activity in murine spleen cells. This mucilage was abundant in the leaf blade of Welsh onion. The aim of this study is to investigate the effect of Welsh onion green leaf extract (GLE) on immune competence in human clinical trials.
\end{abstract}

Methods: A randomized, double-blind, placebo-controlled trial was conducted. Fifty-five healthy subjects were enrolled after the screening based on NK cell activity, and each sample (placebo, low-dose GLE or high-dose GLE) was supplemented for four weeks. The immune competence activity was evaluated through the primary endpoints that were NK cell activity, and the score of immunological vigor (SIV). The SIV was calculated from lymphocyte subset analysis by flow cytometry method.

Results: NK cell activity was enhanced in all supplemented groups including placebo; especially, NK cell activity was significant in both GLE groups. The immune score result showed that the immunity of the high-dose GLE group did not change although it was 
significantly lowered in the placebo group $(\mathrm{p}<0.01)$, suggesting that GLE ameliorated the immunity suppression. In addition, when SIV was compared between pre- and post-intake, the ratios of the improved subjects in two GLE groups were higher than that of the placebo group while those of the aggravated subjects showed the opposite result. In particular, they were remarkable in high-dose GLE group.

Conclusion: These results suggest that the intake of low- or high-dose GLE might positively regulate immune competence.

Keywords: Welsh onion, immunity, natural killer cell, clinical trial

\section{BACKGROUND}

Welsh onion (Allium fistulosum L.) is a major vegetable product that is widely cultivated from Siberia to tropical Asia as well as in Japan, Korea, and China. Allium fistulosum is a member of the onion family Alliaceae. In Japan, Welsh onion, also called bunching onion, is a popular vegetable crop and is commonly used in cooking. It has traditionally been used as an herbal medicine for many ailments such as headache, abdominal pain, diarrhea, and colds. Phytochemical studies reported that organosulfur compounds [1] and polyphenolic compounds [2] were included in Welsh onion. Previous studies have demonstrated the antifungal, anti-oxidative, anti-hypertensive, anti-platelet, and anti-obesity effects of Welsh onion [3-6]. It has also been reported that the extract alters vascular responses in rat aorta [7]. Furthermore, the aqueous extract of its green leaves has been found to decrease tissue nitric oxide and tumor necrosis factor (TNF)- $\alpha$ in mice, leading to an anti-inflammatory effect [8]. Also, a hot-water extract of the green leafy part interfered with an influenza A virus infection by activating the host immune system, and one of its active principles, fructan, contributed to the activation [9]. The most recent investigation has revealed that the oral administration of bunching onion mucus to mice augments the immune functions by increasing TNF- $\alpha$, interleukin (IL)-12, and interferon (IFN) $-\gamma$ production and promoting phagocytosis and natural killer (NK) cell activity [10]. However, the immunostimulatory action of Welsh onion has thus far never been investigated in humans.

The human immune system critically contributes to the host defense. When various pathogens, including viruses, bacteria, and fungi invade the human body; immune systems such as innate and adaptive immunity protect the body from pathogenic attacks. Although the immunocompetent cells consist of lymphoid cells, granulocytic cells and antigen-presenting cells, all of which are associated with defense reactions, the activities of these cells are affected by many kinds of factors including aging, stress, and malnutrition [11-13]. Thus, it is important to maintain normal immune function or to activate that function in healthy people. One of several approaches is to consume nutraceuticals such as functional and healthy foods. However, it is difficult to evaluate the effect of immunomodulatory nutraceuticals in healthy people because their baseline of immune function generally remains steady, and the immunomodulation attributable to functional foods can barely be observed in healthy individuals.

To address this difficulty, Hirokawa and his co-workers developed a scoring system to comprehensively evaluate the immune function using multiple parameters related to $\mathrm{T}$ cells and not simply measuring the cytokine level and/or the number of immunocompetent cells 
$[14,15]$. This method combines seven or eight immunological parameters and expresses the immune status of individuals as a simple numeral. Immunity score standardization is estimated using a database that has been created to measure immunological parameters in many healthy subjects. This score system enables accurate measurement of minor differences in the immune competence of healthy subjects, and the results are given as the score of immunological vigor (SIV). Indeed, we have evaluated with SIV the effect of a standardized extract of cultured Lentinula edodes mycelia (ECLM), which is a functional food derived from mycelial culture of the basidiomycete $[16,17]$ on the seasonal variations of immune competence in healthy subjects [18].

We performed a randomized, double-blind, placebo-controlled study to assess the effect of Welsh onion green leaf extract (GLE) on immune competence in healthy volunteers. In the present study, Hirokawa's immunity scoring system was used to comprehensively evaluate the immune function of healthy subjects between GLE and placebo groups. Furthermore, the safety of GLE supplementation was estimated through hematological and biochemical tests. This study is the first case then where the effect of GLE on immune function has been assessed scientifically in human beings. Preclinical toxicological assessment of GLE has already been conducted in a rat acute oral toxicity study and in genotoxicity studies using bacteria and mice, none of which have indicated that GLE might cause either acute oral toxic or genotoxic effects.

\section{MATERIALS AND METHODS}

\section{Study design}

This study was a randomized, double-blind, placebo-controlled clinical trial taking place across four weeks from November to December. The primary endpoints of the study were the assessment of natural killer (NK) cell activity and the score of immunological vigor (SIV). The other endpoint was determining the safety of Welsh onion green leaf extract (GLE). This study was conducted in accordance with the ethical principles of origins in the Declaration of Helsinki and the protocol was approved by the Ethics Committee of Hokkaido Information University (Ebetsu, Japan; Approval no. 2013-11). All participants gave written informed consent. This study was registered with the University Hospital Medical Information Network (UMIN no. 000017271).

\section{Study subjects}

Healthy adult volunteers were recruited, and among them subjects were excluded from the study based on the following criteria: history of significant illness, current use of any prescribed remedies and supplements involved in immune modulation, any diagnosed medical condition that might confound the safety evaluation, history of allergic reactions to food, and pregnancy. Fifty-five subjects between 30 and 75 years old were randomly assigned to three groups using initial NK cell activity: a placebo group (6 males and 12 females), a low-dose GLE group (6 males and 13 females, GLE $150 \mathrm{mg} /$ day), and a highdose GLE group (6 males and 12 females, GLE $500 \mathrm{mg} /$ day). All subjects ingested daily four capsules of placebo (250 mg dextrin/capsule), low-dose GLE (37.5 mg GLE plus $212.5 \mathrm{mg}$ dextrin/capsule), or high-dose GLE (125 mg GLE plus $125 \mathrm{mg}$ dextrin/capsule) for four weeks. Peripheral blood was collected from all subjects at baseline (pre-intake) and four weeks later (post-intake; final) at the Health Center of Hokkaido Information University. 


\section{Test sample}

GLE was produced from green leaves of Welsh onion (Allium fistulosum L.) and manufactured by Amino Up Co., Ltd. (Sapporo, Japan) according to Good Manufacturing Practice (GMP) standards for dietary supplements and ISO9001:2008 and ISO22000:2005 criteria. Briefly, green leaves of Welsh onion grown in Hokkaido were extracted with hot water at $65^{\circ} \mathrm{C}$ for $30 \mathrm{~min}$. After centrifugation, the supernatant was concentrated in vacuo and spray-dried following sterilization to prepare the GLE powder. The powder was mixed with dextrin (Pinedex, Matsutani Chemical Industry Co., Ltd., Itami, Japan) to prevent consolidation due to its hygroscopic property.

\section{Natural killer cell activity}

Natural killer (NK) cell activity was assessed by chromium-51 $\left({ }^{51} \mathrm{Cr}\right)$ release assay to measure radioactivity released from ${ }^{51} \mathrm{Cr}$-labeled $\mathrm{K} 562$ target cells. This measurement was performed by SRL Inc. (Tokyo, Japan) in a blind manner.

\section{Score of immunological vigor}

The score of immunological vigor (SIV) defined by Hirokawa et al. [14, 15] was estimated according to lymphocyte subset analysis by the flow cytometric method. This score represents the comprehensive immunity strength by scoring various immune indices including the number of $\mathrm{T}$ cells, $\mathrm{CD} 8^{+} \mathrm{CD} 28^{+} \mathrm{T}$ cells, naïve $\mathrm{T}$ cells, $\mathrm{B}$ cells, and NK cells, CD4/CD8 $\mathrm{T}$ cell ratio, and naïve/memory $\mathrm{T}$ cell ratio. Each immune index is individually scored as one of three levels: 1 is "needs improvement," 2 is "needs observation," and 3 is "safe." Hence, the SIV used in the present study was determined from the sum of the seven index scores and therefore ranged from 7 to 21 .

\section{Hematological and biochemical tests}

To assess the safety of GLE consumption, hematological and biochemical parameters were measured at Sapporo Clinical Laboratory Inc. (Sapporo, Japan). Blood was drawn from the subjects before and after intake of the placebo or GLE at the Health Center of Hokkaido Information University and evaluated for white blood cells (WBC), red blood cells (RBC), hemoglobin $(\mathrm{Hb})$, hematocrit $(\mathrm{Ht})$, platelets (Plt), aspartate aminotransferase (AST), alanine aminotransferase (ALT), $\gamma$-glutamyl transpeptidase $(\gamma$-GTP), blood urea nitrogen (BUN), and creatinine (CRE).

\section{Statistical analysis}

All data were collected and analyzed independently of the investigators, who did not have access to the data until the analysis was completed. Data are presented as mean \pm standard deviation (SD). The Mann-Whitney $U$ test was used as a non-parametric test to compare the difference between placebo and GLE groups. The paired Student's $t$-test was performed to compare pre and post-intake values. These analyses were conducted using SPSS (version 20, IBM Corp., Armonk, NY). $P$-values less than 0.05 were considered to be statistically significant. All data were analyzed on a pre-protocol basis.

\section{RESULTS}

\section{General characteristics of study subjects}

Although 55 subjects were enrolled in the current study, one female subject in the high-dose 
Welsh onion green leaf extract (GLE) group was removed for poor compliance with capsule consumption protocols; ultimately, 54 subjects completed the study. The extraneous factors of the study-completed subjects are shown in Table 1. Each factor showed no significant difference between placebo and GLE groups.

\section{Natural killer cell activity}

As shown in Table 2, natural killer (NK) cell activity following four-week supplementation (post-intake; final) was significantly enhanced in the placebo $(p<0.05)$, low-dose GLE $(p<0.01)$, and high-dose GLE $(p<0.01)$ groups, compared to each baseline (pre-intake). The difference in NK cell activity (\%) between baseline and final was $5.5 \pm 9.6,10.9 \pm 8.5$, and $10.4 \pm 7.0$ in the placebo, low-dose GLE, and high-dose GLE groups, respectively. The increased level was greater in the GLE groups than the placebo group, but it was not statistically significant.

Table 1 Background factors of the study subjects

\begin{tabular}{|c|c|c|c|}
\hline Factors & Placebo & Low-dose GLE & High-dose GLE \\
\hline \multicolumn{4}{|l|}{ Sample size (n) } \\
\hline Total & 18 & 19 & 17 \\
\hline Male & 6 & 6 & 6 \\
\hline Female & 12 & 13 & 11 \\
\hline \multicolumn{4}{|l|}{ Age (y.o.) } \\
\hline Mean \pm SD & $54.2 \pm 12.0$ & $56.7 \pm 8.3$ & $53.7 \pm 11.0$ \\
\hline \multicolumn{4}{|c|}{ Body height $(\mathrm{cm})$} \\
\hline Mean \pm SD & $160.2 \pm 8.6$ & $160.3 \pm 8.6$ & $159.8 \pm 7.6$ \\
\hline \multicolumn{4}{|c|}{ Body weight $(\mathrm{kg})$} \\
\hline Mean \pm SD & $57.2 \pm 12.3$ & $57.1 \pm 10.8$ & $59.5 \pm 11.7$ \\
\hline \multicolumn{4}{|l|}{ BMI } \\
\hline Mean \pm SD & $22.1 \pm 2.7$ & $22.1 \pm 3.0$ & $23.1 \pm 3.4$ \\
\hline
\end{tabular}

Table 2 Alteration of NK cell activity

\begin{tabular}{lccc}
\hline NK cell activity $(\%)$ & Placebo & Low-dose GLE & High-dose GLE \\
\hline Baseline & $36.9 \pm 11.8$ & $37.3 \pm 11.3$ & $38.6 \pm 10.8$ \\
Final & $42.4 \pm 13.7^{*}$ & $48.3 \pm 13.3^{* *}$ & $48.9 \pm 13.1^{* *}$ \\
\hline
\end{tabular}

Abbreviations: NK, natural killer; GLE, Welsh onion green leaf extract.

Values are mean \pm SD. $* \mathrm{p}<0.05$ and $* * \mathrm{p}<0.01$ indicate a significant difference between baseline and final.

\section{Score of immunological vigor}

Score of immunological vigor (SIV) was calculated from lymphocyte subset analysis responsible for seven immune parameters: the numbers of $\mathrm{T}$ cells, $\mathrm{CD} 8^{+} \mathrm{CD} 28^{+} \mathrm{T}$ cells, naïve $\mathrm{T}$ cells, $\mathrm{B}$ cells, and NK cells, CD4/CD8 $\mathrm{T}$ cell ratio, and naïve/memory $\mathrm{T}$ cell ratio, all of which were measured by the flow cytometric method. The results including SIV are presented in Table 3. SIV was significantly decreased in the placebo group $(p<0.01)$ and the low-dose GLE group $(p<0.05)$ after four-week consumption. In the SIV variation between baseline and final, the change ratio of the placebo group was significantly deteriorated compared to those of the low- and high-dose GLE groups $(p<0.05)$. 
Table 3. Results of lymphocyte subset analysis and SIV

\begin{tabular}{|c|c|c|c|c|c|c|}
\hline \multirow[b]{2}{*}{ Parameters } & \multicolumn{2}{|c|}{ Placebo } & \multicolumn{2}{|c|}{ Low-dose GLE } & \multicolumn{2}{|c|}{ High-dose GLE } \\
\hline & $\begin{array}{l}\text { Baselin } \\
\mathrm{e}\end{array}$ & Final & $\begin{array}{c}\text { Baselin } \\
\mathrm{e}\end{array}$ & Final & $\begin{array}{c}\text { Baselin } \\
\mathrm{e}\end{array}$ & Final \\
\hline $\mathrm{T}$ cells $(/ \mu \mathrm{L})$ & $\begin{array}{l}1,295 \pm \\
503\end{array}$ & $\begin{array}{l}1,346 \pm \\
668\end{array}$ & $\begin{array}{l}1,323 \pm \\
393\end{array}$ & $\begin{array}{l}1,370 \pm \\
429\end{array}$ & $\begin{array}{l}1,170 \pm \\
512\end{array}$ & $\begin{array}{l}1,115 \pm \\
393\end{array}$ \\
\hline $\begin{array}{l}\text { CD8+CD28+ T } \\
\text { cells }(/ \mu \mathrm{L})\end{array}$ & $\begin{array}{l}244.2 \pm \\
92.9\end{array}$ & $\begin{array}{l}230.1 \pm \\
127.5\end{array}$ & $\begin{array}{l}256.9 \pm \\
88.2\end{array}$ & $\begin{array}{l}206.6 \pm \\
88.4 * *\end{array}$ & $\begin{array}{l}247.1 \pm \\
140.1\end{array}$ & $\begin{array}{l}212.8 \pm \\
126.6\end{array}$ \\
\hline $\begin{array}{l}\text { Naïve T cells } \\
(/ \mu \mathrm{L})\end{array}$ & $\begin{array}{l}362.6 \pm \\
218.7\end{array}$ & $\begin{array}{l}336.3 \pm \\
203.9\end{array}$ & $\begin{array}{l}365.4 \pm \\
180.2\end{array}$ & $\begin{array}{l}385.9 \pm \\
202.3\end{array}$ & $\begin{array}{l}294.8 \pm \\
168.2\end{array}$ & $\begin{array}{l}282.4 \pm \\
151.6\end{array}$ \\
\hline $\mathrm{B}$ cells $(/ \mu \mathrm{L})$ & $\begin{array}{l}275.2 \pm \\
133.2\end{array}$ & $\begin{array}{l}139.7 \pm \\
64.3 * *\end{array}$ & $\begin{array}{l}252.7 \pm \\
88.9\end{array}$ & $\begin{array}{l}174.2 \pm \\
85.1 * *\end{array}$ & $\begin{array}{l}260.9 \pm \\
135.3\end{array}$ & $\begin{array}{l}159.3 \pm \\
91.9 * *\end{array}$ \\
\hline NK cells $(/ \mu \mathrm{L})$ & $\begin{array}{l}201.6 \pm \\
101.8\end{array}$ & $\begin{array}{l}157.1 \pm \\
71.8\end{array}$ & $\begin{array}{l}206.4 \pm \\
141.1\end{array}$ & $\begin{array}{l}153.4 \pm \\
89.6\end{array}$ & $\begin{array}{l}215.4 \pm \\
151.3\end{array}$ & $\begin{array}{l}198.1 \pm \\
145.8\end{array}$ \\
\hline $\begin{array}{l}\text { CD4/CD8 T cell } \\
\text { ratio }\end{array}$ & $\begin{array}{l}2.19 \pm \\
0.73\end{array}$ & $\begin{array}{l}2.45 \pm \\
0.99\end{array}$ & $\begin{array}{l}2.44 \pm \\
1.06\end{array}$ & $\begin{array}{l}3.02 \pm \\
1.28 * *\end{array}$ & $\begin{array}{l}2.51 \pm \\
1.80\end{array}$ & $\begin{array}{l}2.86 \pm \\
2.25^{*}\end{array}$ \\
\hline $\begin{array}{l}\text { Naïve/memory } \mathrm{T} \\
\text { cell ratio }\end{array}$ & $\begin{array}{l}0.712 \pm \\
0.344\end{array}$ & $\begin{array}{l}0.674 \pm \\
0.291\end{array}$ & $\begin{array}{l}0.714 \pm \\
0.400\end{array}$ & $\begin{array}{l}0.763 \pm \\
0.424\end{array}$ & $\begin{array}{l}0.584 \pm \\
0.290\end{array}$ & $\begin{array}{l}0.622 \pm \\
0.377\end{array}$ \\
\hline SIV & $\begin{array}{l}16.7 \pm \\
2.3\end{array}$ & $\begin{array}{l}15.5 \pm \\
2.3 * *\end{array}$ & $\begin{array}{l}16.9 \pm \\
2.0\end{array}$ & $\begin{array}{l}16.3 \pm \\
1.7^{*}\end{array}$ & $\begin{array}{l}15.4 \pm \\
2.6\end{array}$ & $\begin{array}{l}15.3 \pm \\
2.8\end{array}$ \\
\hline SIV variation $(\%)$ & \multicolumn{2}{|c|}{$-7.2 \pm 8.1$} & \multicolumn{2}{|c|}{$-3.4 \pm 6.9^{\#}$} & \multicolumn{2}{|c|}{$-0.8 \pm 6.3^{\#}$} \\
\hline
\end{tabular}

Abbreviations: GLE, Welsh onion green leaf extract; NK, natural killer; SIV, score of immunological vigor.

Values are mean \pm SD. ${ }^{*} \mathrm{p}<0.05$ and $* * \mathrm{p}<0.01$ indicate a significant difference between baseline and final. ${ }^{\#} \mathrm{p}<0.05$ shows a significant difference from the placebo group. SIV variation $=($ Final SIV - Baseline SIV)/Baseline SIV x 100

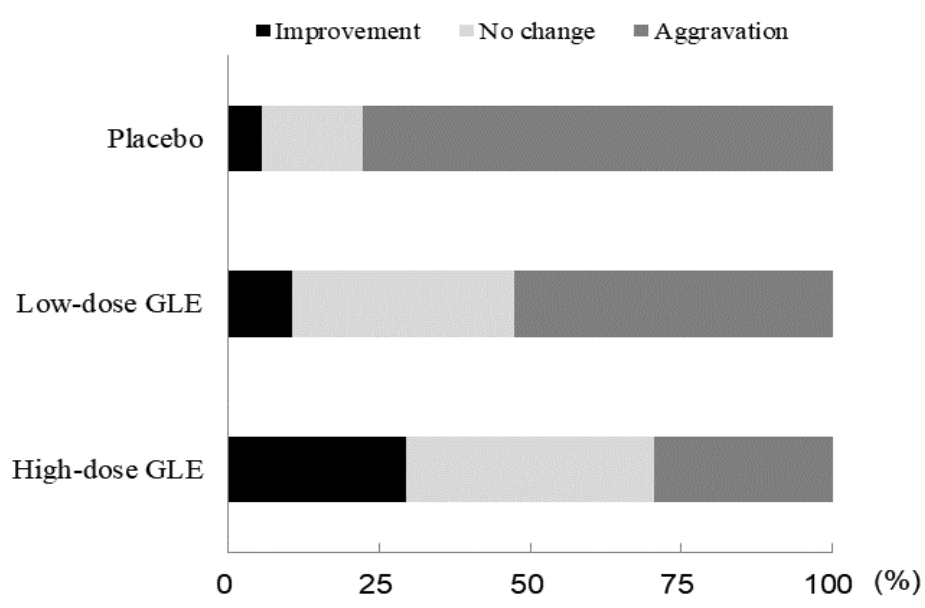

Figure 1. The ratio of each group on the basis of SIV change. The alteration between pre- and post-intake was divided into three categories, which were improvement, no change and aggravation, and the percent was calculated in each group. The percent values of improvement, no change and aggravation were respectively 5.6, 16.7 and 77.8 in the placebo group, 10.5, 36.8 and 52.6 in the lowdose GLE group, and 29.4, 41.2 and 29.4 in the high-dose GLE group.

Abbreviations: GLE, Welsh onion green leaf extract 
Furthermore, the change of SIV in each subject of all groups was classified into three stages: "improvement (increased SIV)," "no change," and "aggravation (decreased SIV)" in order to simplify the response of SIV attributable to GLE intake. Compared to the placebo group, the percentage of "aggravation" was lower, whereas that of "improvement" was higher in both GLE groups as shown in Figure 1. The predisposition was predominant in the highdose GLE group.

\section{Safety data}

Throughout the four-week study, the subjects reported no serious adverse events on health due to placebo or GLE consumption and the compliance was over $85 \%$. The changes of all hematological and biochemical parameters in Table 4 were normal or negligibly small in placebo- and GLE-supplemented subjects although the number of white blood cells was significantly lowered following four-week ingestion in the high-dose GLE group ( $p<0.05$ vs baseline).

Table 4. Hematological and biochemical tests

\begin{tabular}{|c|c|c|c|c|c|c|}
\hline \multirow{2}{*}{$\begin{array}{l}\text { Parameters } \\
\text { (Standard value) }\end{array}$} & \multicolumn{2}{|c|}{ Placebo } & \multicolumn{2}{|c|}{ Low-dose GLE } & \multicolumn{2}{|c|}{ High-dose GLE } \\
\hline & Baseline & Final & Baseline & Final & Baseline & Final \\
\hline WBC (3.5-9.7 x & $5.51 \pm$ & $5.66 \pm$ & $5.49 \pm$ & $5.15 \pm$ & $5.32 \pm$ & $4.68 \pm$ \\
\hline $\left.10^{3} / \mu \mathrm{L}\right)$ & 1.21 & 1.33 & 1.18 & 1.46 & 1.73 & $0.99 *$ \\
\hline RBC (438-577 x & $447.4 \pm$ & $447.3 \pm$ & $452.3 \pm$ & $445.5 \pm$ & $440.2 \pm$ & $436.1 \pm$ \\
\hline $\left.10^{4} / \mu \mathrm{L}\right)$ & 37.8 & 41.5 & 40.6 & 39.7 & 38.8 & 39.7 \\
\hline $\mathrm{Hb}(13.6-18.3 \mathrm{~g} / \mathrm{dL})$ & $\begin{array}{c}13.67 \pm \\
1.23\end{array}$ & $\begin{array}{c}13.71 \pm \\
1.46\end{array}$ & $\begin{array}{c}13.98 \pm \\
1.25\end{array}$ & $\begin{array}{c}13.81 \pm \\
1.25\end{array}$ & $\begin{array}{c}13.44 \pm \\
1.35\end{array}$ & $\begin{array}{c}13.37 \pm \\
1.53\end{array}$ \\
\hline Ht (40.4-51.9\%) & $\begin{array}{c}40.59 \pm \\
3.39\end{array}$ & $\begin{array}{c}41.32 \pm \\
4.01\end{array}$ & $\begin{array}{c}41.34 \pm \\
2.89\end{array}$ & $\begin{array}{c}41.23 \pm \\
3.28\end{array}$ & $\begin{array}{c}39.67 \pm \\
3.43\end{array}$ & $\begin{array}{c}40.15 \pm \\
3.73\end{array}$ \\
\hline $\begin{array}{l}\text { Plt }(14.0-37.9 \times \\
\left.10^{4} / \mu \mathrm{L}\right)\end{array}$ & $\begin{array}{c}25.36 \pm \\
7.28\end{array}$ & $\begin{array}{c}25.91 \pm \\
6.04\end{array}$ & $\begin{array}{c}23.03 \pm \\
4.71\end{array}$ & $\begin{array}{c}23.72 \pm \\
5.63\end{array}$ & $\begin{array}{c}23.52 \pm \\
4.45\end{array}$ & $\begin{array}{c}23.71 \pm \\
4.18\end{array}$ \\
\hline AST (10-40 U/L) & $\begin{array}{c}24.0 \pm \\
7.5\end{array}$ & $\begin{array}{c}23.6 \pm \\
7.6\end{array}$ & $\begin{array}{c}24.7 \pm \\
14.3\end{array}$ & $\begin{array}{c}26.6 \pm \\
20.3\end{array}$ & $\begin{array}{c}22.6 \pm \\
7.2\end{array}$ & $\begin{array}{c}23.8 \pm \\
7.2\end{array}$ \\
\hline $\operatorname{ALT}(5-45 \mathrm{U} / \mathrm{L})$ & $\begin{array}{c}22.8 \pm \\
13.3\end{array}$ & $\begin{array}{c}21.2 \pm \\
11.0\end{array}$ & $\begin{array}{c}24.1 \pm \\
18.7\end{array}$ & $\begin{array}{c}24.3 \pm \\
23.7\end{array}$ & $\begin{array}{c}20.9 \pm \\
13.6\end{array}$ & $\begin{array}{c}22.5 \pm \\
17.4\end{array}$ \\
\hline$\gamma$-GTP $(1-79 \mathrm{U} / \mathrm{L})$ & $\begin{array}{c}29.2 \pm \\
23.8\end{array}$ & $\begin{array}{l}28.2 \pm \\
23.6\end{array}$ & $\begin{array}{c}40.5 \pm \\
38.0\end{array}$ & $\begin{array}{c}40.2 \pm \\
46.4\end{array}$ & $\begin{array}{c}41.4 \pm \\
61.7\end{array}$ & $\begin{array}{c}40.4 \pm \\
55.9\end{array}$ \\
\hline $\begin{array}{l}\text { BUN (8.0-20.0 } \\
\mathrm{mg} / \mathrm{dL})\end{array}$ & $\begin{array}{c}13.89 \pm \\
3.66\end{array}$ & $\begin{array}{c}13.44 \pm \\
3.06\end{array}$ & $\begin{array}{c}15.08 \pm \\
2.57\end{array}$ & $\begin{array}{c}14.75 \pm \\
1.78\end{array}$ & $\begin{array}{c}14.92 \pm \\
3.50\end{array}$ & $\begin{array}{c}14.99 \pm \\
3.90\end{array}$ \\
\hline $\begin{array}{l}\mathrm{CRE}(0.65-1.09 \\
\mathrm{mg} / \mathrm{dL})\end{array}$ & $\begin{array}{c}0.692 \pm \\
0.125\end{array}$ & $\begin{array}{c}0.707 \pm \\
0.125\end{array}$ & $\begin{array}{c}0.707 \pm \\
0.101\end{array}$ & $\begin{array}{c}0.706 \pm \\
0.099\end{array}$ & $\begin{array}{c}0.743 \pm \\
0.142\end{array}$ & $\begin{array}{c}0.771 \pm \\
0.128\end{array}$ \\
\hline
\end{tabular}

Abbreviations: GLE, Welsh onion green leaf extract; WBC, white blood cells; RBC, red blood cells; Hb, hemoglobin; Ht, hematocrit; Plt, platelets; AST, aspartate aminotransferase; ALT, alanine aminotransferase; $\gamma$-GTP, $\gamma$-glutamyl transpeptidase; BUN, blood urea nitrogen; CRE, creatin.

Values are mean \pm SD. All parameters except for WBC showed no significant differences among three groups, and between baseline and final. ${ }^{*} \mathrm{p}<0.05$ represents a significant difference between baseline and final. 


\section{DISCUSSION}

The present research was performed as a pilot study recruiting healthy volunteers in order to determine whether Welsh onion green leaf extract (GLE) upregulates immune competence. Natural killer (NK) cell count and its activity were estimated in this study, which are thought to be the main factors in innate immunity related to initial defense against pathogens [19]. All NK cell counts in the placebo, low-dose GLE, and high-dose GLE groups were decreased as shown in Table 3. This phenomenon might be attributable to the fact that this study was conducted in winter because the previous investigation reported that NK cells decrease in winter [20, 21]. However, the reduction in the high-dose GLE group was smaller than that of the placebo group. On the other hand, NK cell activities were significantly increased in all three groups (Table 2), which could be considered counteraction to NK cell count decreases. Elevated NK cell levels in both GLE groups were greater compared to the placebo group. The findings in the placebo group are consistent with the report that the NK cell count and its activity were decreased and increased, respectively, in the healthy human study conducted in winter [18]. Thus, these results suggest that GLE consumption attenuated the reduction of NK cell count and enhanced NK cell activity although it had no dose response.

The score of immunological vigor (SIV) result indicates that the comprehensive immune function was not altered in the high-dose GLE group while it was significantly decreased in the placebo and low-dose GLE groups as shown in Table 3. The variation of SIV between baseline and final was smaller in the low-dose and high-dose GLE groups than in the placebo group, and the reduced change ratio of the placebo group was statistically significant compared to those of the low- and high-dose GLE groups. This observation in the placebo group is also identical to the result from the previous study on ECLM [18]. SIV was calculated from lymphocyte subset analysis for seven immune parameters, and B cells were remarkably decreased between baseline and final in all three groups. The other in vivo experiment revealed that the proportion of $\mathrm{T}$ cytotoxic-suppressor lymphocytes was significantly higher in summer and autumn than in winter and spring, and the proportion of $\mathrm{B}$ lymphocytes was significantly lower in spring [22]. In this case, although the reduction in B cells might be attributed to seasonal variation, the decrease was suppressed in the subjects supplemented with GLE. Also, the CD4/CD8 T cell ratio was significantly elevated between pre- and post-consumption of GLE. In the recent study, it has been reported that the ratio of CD4/CD8 $T$ lymphocytes was positively correlated with the plasma level of 1,25dihydroxyvitamin D3, which was lower in patients with pulmonary tuberculosis than in healthy adults [23]. The observation suggests that the increased CD4/CD8 T cell ratio might contribute to the resistance of infectious diseases including tuberculosis. Moreover, the ratio of subjects with increased and decreased SIV was respectively higher and lower in the GLE groups than the placebo group [Figure 1], and the effect of GLE was observed in a dosedependent manner. From these results, supplementation with GLE could positively regulate SIV, which reflects the comprehensive immune function, in addition to B cells and the CD4/CD8 T cell ratio, which are themselves constitutive parameters of SIV.

Simultaneously, the safety of GLE was assessed in the present clinical trial. White blood cell count in the high-dose GLE group was significantly decreased as shown in Table 4; however, the value of post-consumption was normal within the standard value. Additionally, several parameters such as red blood cells (RBC), hemoglobin (Hb), and hematocrit (Ht) deviated from each standard value in the high-dose GLE group. In regard to $\mathrm{Hb}$ and $\mathrm{Ht}$, their baseline values were already under normal level, and the deviance of RBC was a negligible alteration. Other parameters of the high-dose GLE group and all parameters of the placebo 
and low-dose GLE groups showed normal levels. Thus, it was suggested that four-week consumption of GLE at $500 \mathrm{mg} /$ day might be safe for healthy male and female adults at least.

Recently, one of the active components derived from an Allium fistulosum hot-water extract has been identified to be fructan, which has been found to contribute to an antiinfluenza effect [9]. Fructan from an aged garlic extract has also been reported to possess a delayed immunoadjuvant response to ovalbumin antigen in BALB/c mice [24]. Therefore, Ueda et al. examined the effects of already known ingredients such as allicin that is characteristic of the Allium species, fructan, and fructose; however, they were unable to activate immune response in mice [10]. The mucus of Welsh onion exhibited the TNF- $\alpha$ inducing activity on RAW 264 cells [10, 25]. This effect was mainly attributed to mannosebinding lectin and thaumatin-like proteins, which were separated from leaf mucus of Welsh onion [25]. If these proteins had a significant effect on human immune system, they may contribute to the immunomodulatory function of GLE in this trial. Further studies are needed to determine an active ingredient exerting the effect of GLE proven in the present study.

In Japan, particularly in eastern Japan including Hokkaido, green leaves of Welsh onion are considered to be unsuitable for consumption and are discarded as waste. Although Hokkaido is a big production base for Welsh onion, the waste material is a burden to the farm producers. Thus, to address the problem, we sought to find out a use for the leaves of Welsh onion by establishing evidence that GLE modulates the immune competence of healthy adult. However, this study was conducted with a small sample size and for a short period of time. Therefore, larger-scale and longer-term trials are needed in a proof-of concept stage.

\section{CONCLUSIONS}

The current study demonstrates that successive four-week ingestion of low- or high-dose GLE could maintain and enhance immune function in healthy adults. The results also suggest that GLE might contribute to preventing infectious diseases such as the common cold and influenza.

List of Abbreviations: NK cell, natural killer cell; GLE, green leaf extract; TNF- $\alpha$, tumor necrosis factor- $\alpha$; IL, interleukin; IFN, interferon; SIV, score of immunological vigor; ${ }^{51} \mathrm{Cr}$, chromium-51; WBC, white blood cells; RBC, red blood cells; Hb, hemoglobin; Ht, hematocrit; Plt, platelets; AST, aspartate aminotransferase; ALT, alanine aminotransferase; $\gamma$ GTP, $\gamma$-glutamyl transpeptidase; BUN, blood urea nitrogen; CRE, creatinine; SD, standard deviation.

Competing Interests: All authors declared no potential conflicts of interest in terms of the research, authorship and/or publication of this article.

Authors' Contributions: YH, JT, AT and JN participated in the design of the study and contributed to data analysis. YH and KG drafted the manuscript. HU and JN supervised the investigation. All authors reviewed and approved the final version of the article.

Acknowledgments and Funding: We would like to acknowledge the Northern Advancement Center for Science \& Technology (Sapporo, Japan) for providing financial assistance. The authors disclosed receipt of the following financial support for the research, 
authorship and/or publication of the article. This study was supported by a research grant from the Northern Advancement Center for Science \& Technology.

\section{REFERENCES}

1. Zhou Y, Zhuang W, Hu W, Liu GJ, Wu TX, Wu XT: Consumption of large amounts of Allium vegetables reduces risk forgastric cancer in a meta-analysis. Gastroenterology 2011, 141(1): 80-89.

2. Vlase L, Parvu M, Parvu EA, Toiu A: Phytochemical analysis of Allium fistulosum L. and A. ursinum L.. Digest Journal of Nanomaterials \& Biostructures 2013, 8(1): 457-467.

3. Sang S, Lao A, Wang Y, Chin CK, Rosen RT, Ho CT: Antifungal constituents from the seeds of Allium fistulosum. L. J Agric Food Chem 2002, 50(22): 63186321.

4. Yamamoto Y, Aoyama S, Hamaguchi N, Rhi GS: Antioxidative and antihypertensive effects of Welsh onion on rats fed with a high-fat high-sucrose diet. Biosci Biotechnol Biochem 2005, 69(7): 1311-1317.

5. Chen JH, Chen HI, Wang JS, Tsai SJ, Jen CJ: Effects of Welsh onion extracts on human platelet function in vitro. Life Sci 2000, 66(17): 1571-1579.

6. Sung YY, Yoon T, Kim SJ, Yang WK, Kim HK: Anti-obesity activity of Allium fistulosum L. extract by down-regulation of the expression of lipogenic genes in high-fat diet-induced obese mice. Mol Med Rep 2011, 4(3): 431-435.

7. Chen JH, Tsai SJ, Chen HI: Welsh onion (Allium fistulosum L.) extracts alter vascular responses in rat aortae. J Cardiovasc Pharmacol 1999, 33(4): 515-520.

8. Wang BS, Huang GJ, Lu YH, Chang LW: Anti-inflammatory effects of an aqueous extract of Welsh onion green leaves in mice. Food Chem 2013, 138(2-3): 751-756.

9. Lee JB, Miyake S, Umetsu R, Hayashi K, Chijimatsu T, Hayashi T: Anti-influenza A virus effects of fructan from Welsh onion (Allium fistulosum L.). Food Chem 2012, 134(4): 2164-2168.

10. Ueda H, Takeuchi A, Wako T: Activation of immune responses in mice by an oral administration of bunching onion (Allium fistulosum) mucus. Biosci Biotechnol Biochem 2013, 77(9): 1809-1813.

11. Shaw AC, Goldstein DR, Montgomery RR: Age-dependent dysregulation of innate immunity. Nat Rev Immunol 2013, 13(12): 875-887.

12. Segerstrom SC, Miller GE: Psychological stress and the human immune system: a meta-analytic study of 30 years of inquiry. Psychol Bull 2004, 130(4): 601-630.

13. Cunningham-Rundles S, McNeeley DF, Moon A: Mechanisms of nutrient modulation of the immune response. J Allergy Clin Immunol 2005, 115(6): 11191128.

14. Hirokawa K, Utsuyama M, Kikuchi Y, Kitagawa M: Scoring of immunological vigor: Trial assessment of immunological status as a whole for elderly people and cancer patients. In: Pawlec G, ed. Immunosenescence. New York, NY: Springer, 2007: 15-21.

15. Hirokawa K, Utsuyama M, Ishikawa $\mathrm{T}$, et al.: Decline of $\mathrm{T}$ cell-related immune functions in cancer patients and an attempt to restore them through infusion of activated autologous T cells. Mech Ageing Dev 2009, 130(1-2): 86-91. 
16. Tanaka Y, Ohashi S, Ohtsuki A, et al.: Adenosine, a hepato-protective component in active hexose correlated compound: its identification and iNOS suppression mechanism. Nitric Oxide 2014, 40: 75-86.

17. Mascaraque C, Suárez MD, Zarzuelo A, Sánchez de Medina F, Martínez-Augustin O: Active hexose correlated compound exerts therapeutic effects in lymphocyte driven colitis. Mol Nutr Food Res 2014, 58(12): 2379-2382.

18. Takanari J, Hirayama Y, Homma K, Miura T, Nishioka H, Maeda T: Effects of active hexose correlated compound on the seasonal variations of immune competence in healthy subjects. J Evid Based Complementary Altern Med 2015, 20(1): 28-34.

19. Paolini R, Bernardini G, Molfetta R, Santoni A: NK cells and interferons. Cytokine Growth Factor Rev 2015, 26(2): 113-120.

20. Lévi FA, Canon C, Touitou Y, Reinberg A, Mathé G: Seasonal modulation of the circadian time structure of circulating $\mathrm{T}$ and natural killer lymphocyte subsets from healthy subjects. J Clin Invest 1988, 81(2): 407-413.

21. Rama L, Teixeira AM, Matos A, et al.: Changes in natural killer cell subpopulations over a winter training season in elite swimmers. Eur J Appl Physiol 2013, 113(4): 859-868.

22. Planelles D, Hernández-Godoy J, Montoro A, Montoro J, González-Molina A: Seasonal variation in proliferative response and subpopulations of lymphocytes from mice housed in a constant environment. Cell Prolif 1994, 27(6): 333-341.

23. Gao WW, Wang Y, Zhang XR, et al.: Levels of 1,25(OH)2D3 for patients with pulmonary tuberculosis and correlations of $1,25(\mathrm{OH}) 2 \mathrm{D} 3$ with the clinical features of TB. J Thorac Dis 2014, 6(6): 760-764.

24. Chandrashekar PM, Venkatesh YP: Fructans from aged garlic extract produce a delayed immunoadjuvant response to ovalbumin antigen in BALB/c mice. Immunopharmacol Immunotoxicol 2012; 34(1), 174-180.

25. Yamazaki T, Ogawa T, Muramoto K, Nakahigashi J, Takeuchi A, Ueda H: Isolation and biochemical characterization of mucus proteins in Japanese bunching onion (Allium fistulosum) green leaves. Food Science and Technology Research 2016, 22(2): 235-243. 